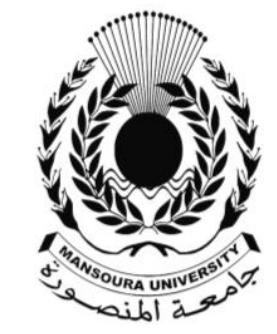

جامعة المنصـورة المانفة

كليـة الآداب

\title{
الاحتجاج على النيوليبرالية الاقتصادية في إسرائيل \\ فى الجموعة الشعرية "أشعار الخيام"
}

\author{
إعــد/د \\ هيام محمد أحمد محملد سليمان \\ باحثة لارجة الماجستير بقسم اللغات الثرقية \\ كلية الآداب - جامعة المنصورة$$
\text { إشراف }
$$

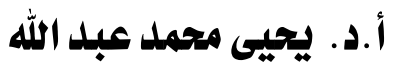 \\ استاذ اللغة العبرية \\ كلية الآداب -جامعة المنصورة \\ مجـلة كلــية الآداب - جـامعـة المنصــورة

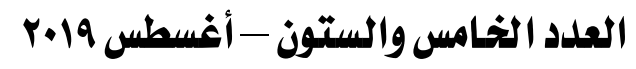




\section{1الإتجاج على النيوليبرالية الاقتصادية في إسرائيل فى المجمو عة الشعرية ديوان الثورة \\ "أشعار الفيام" שירון המהפכה "שירת האוהלים"}

\section{هيام محمد أحمل محمد سليمان}

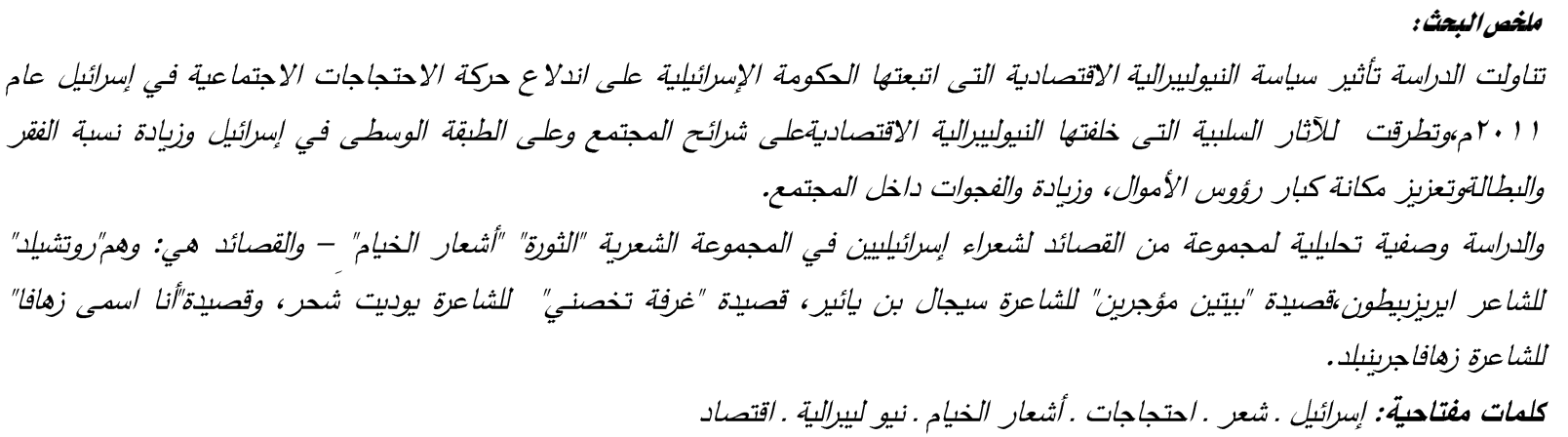

Abstract:

The study discussed the impact of the economic neoliberal policy adopted by the Israeli government in the outbreak of the social protest movement in Israel in 2011.Also it touched upon the negative effects of economic neo-liberalism on society and the middle class in Israel, increasing poverty and unemployment, strengthening the status of large capital and increasing inequality and gaps in society.

the study is an descriptive and analytical one. It dealt with a collection of poems wrote by Israeli poets in the poetry collection "The Revolution", "Poems of the Tents". The poems are: "Rothschild" by ErezBitton, "Two Rented Houses" by Sigal Ben Yair,"Room belongs to me" by Judith Shahar, "My Name Is Zahava" by ZahavaGrinbald.

Keywords: Israel - poetry - protests - protest tents - neoliberal economy

\section{أسباب اختيار اللدراسة}

مقدمــــة :

ترجع أسباب اختيار الدراسة إلى ملاحظة الدور

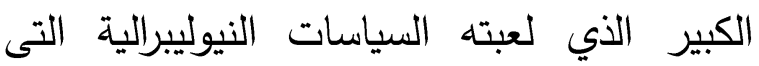

اتبعتها الحكومات الاسرائيلية المتعاقبة فى العقود

الثلاثة الأخيرة فى التأثير على حركة المجتمع.

\section{أهداف الدراسة}

يهدف البحث إلى الوقوف على التأثير السلبي

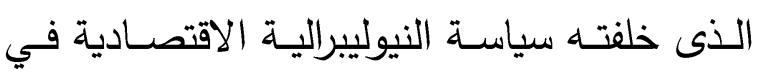

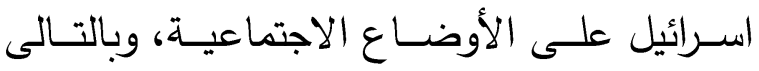

$$
\text { تسببها فى اشتعال احتجاجات الخيام. }
$$

أهمية الدراسة : تكمن أهمية الدراسة في طبيعة

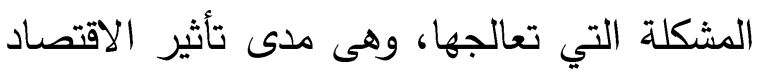

$$
\text { على الوضع الاجتماعي في إسرائيل. }
$$

تتناول الدراسة حركة الاحتجاجات الاجتماعية

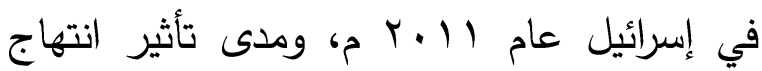
سياسة النيوليبرالية الاقتصادية على اندلاع تلك فلك فليز الاحتجاجات، وذلك من خلال دراسة وصفية تحليلية لمجموعة من التصائد في المجموعة الثعرية "الثورة" "أشعار الخيام" كوهي مجموعة لهنية شعرية حررها عدد من الثعراء الاسرائيليين - شعني منهم على سبيل المثال لا الحصر : يوديت شحر، أهرون شبتاى، روني هيرش، يعرا شحوري، ماتي

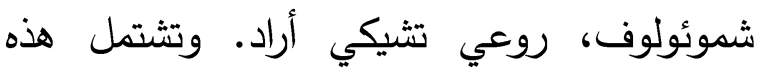
المجموعة الثعرية على قصائد كتبها شعراء شاركوا فى هذه الاحتجاجات. 
لعدة أسباب كان أهمها أن اندلاع تلك الأ منهجية اللدراسة

الاحتجاجات جاء من الطبقة الوسطى، ذات

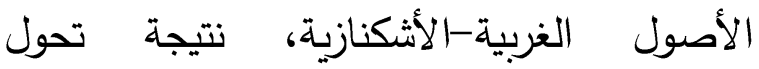
الاقتصاد الإسرائيلي من النظام الآشتراكي إلى الى الئه النظام الرأسمالي النيوليبرالي بحيث فاق مايمكن الإنيل أن تتحمله الطبقات الوسطى (') والنيولييرالية هى بداية نظرية فى ممارسات الاقتصاد السياسي تفترض أن أفضل وسيلة لتعزيز سعادة الانسان ورخائه تكمن فى إطلاق حريات الفرد ومهاراته فى القيام بمشاريعه وأعماله ضمن إطار مؤسساتى يتصف بحقوق قوية

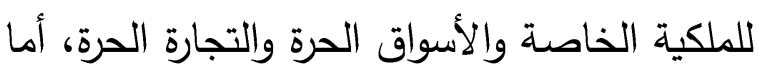
دور الدولة فيقتصر على خلق الإطار المؤسساتى والحفاظ عليه عن طريق الوظائف العسكرية والدفاعية والثرطية والقانونية اللازمة لتأمين

حقوق الملكية الخاصة (广). لابد من تقديم نبذة حول تطور الفكر الاقتصادي

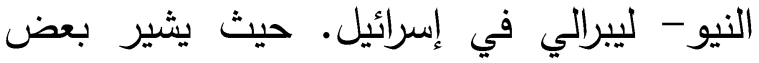
علماء الاقتصاد إلى منتصف عقد الثمانينات من القرن الماضي على أنه بداية التحول الرسمي في التي

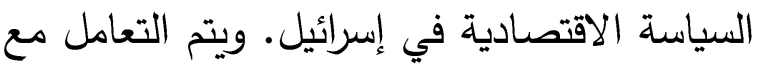
برنامج "التثبيت الاقتصادي" الذي انطلق سنة

' - إمطانس شحادة، حركة الاحتجاج الإسرائيلية من منظور اقتصادي سياسي، المركز العربي للأبحاث ودراسة السياسات، كموقع عرب ^ـ ، ، تاريخ النشر : ب r- الوجيز فى تاريخ النيولييرالية، تأليف ديفيد هارفي، ترجمة وليد شحادة، منشورات الهيئة العامة السورية

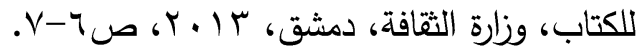

اعتمد البحث على المنهج التاريخي والمنهج الوصفي التحليلي، حيث يستعرض السياسة الاقتصادية للحكومات الاسرائيلية خلال العقود الأخيرة والأثار السلبية التي خلفتها على الوضع الاجتماعي بثكل عام في إسرائيل.

\section{المشكلات التي واجهت الباحثة}

هناك بعض المشكلات التي واجهت الباحث

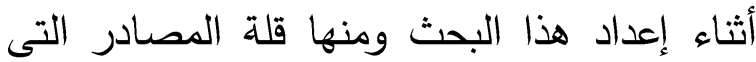

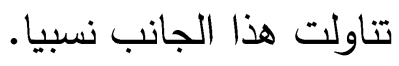

\section{اللدراسات السابقة}

هناك دراسات سابقة تناولت هذا الموضوع، باللغة العربية وكذلك باللغة العبرية. وبالنسبة لللدراسات العربية ذات الصلة بموضوع البحث لئه دراسة بعنوان (حركة الاحتجاج الإسرائيلية من منظور اقتصادي سياسي للكاتب إمطانس شحادة

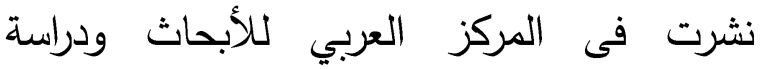
السياسات) ، أما الدراسات العبرية هنالك دراسة بعنوان ( الاحتجاج الاجتماعى والاقتصاد الاسرائيلى للكاتب يوسف زعيرا - המחאה الان החברתית וכלכלת ישראל).

تتمركز الدراسة حول أسباب اندلاع حركة الاحتجاج الاجتماعي التى اجتاحت إسرائيل فى

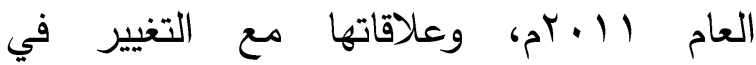
السياسات الاقتصادية الإسرائيلية خاصة العقود الثلاثة الأخيرة. حيث جاءت حركة الاحتجاج مفاجئة بعض الثيء في المشهد الإسرائيلي وذلك الايك 
اكتوبر عام 9VV ام، محدثة ماهو أثبه بانقلاب اقتصادي داخل إسرائيل ، تمثل أساسا في إلغاء الرقابة على العملة الصعبة ، وتعويم الليرة، وإجراء تخفيض كبير في قيمتها، من خلال توحيد قيمة صرفها، ثم رفع ضريبة القيمة الإضافية (بعد الغاء ضريبة الشراء)، وخفض الإعانات الحكومية للمواد الاستهلاكية الأساسية، كذلك ألغيت الحوافز

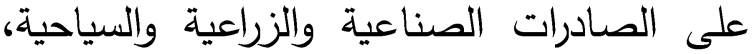

$$
\text { وسمح بالاستيراد الحر (o.). }
$$

وكان تأثير السياسة الاقتصادية الجديدة على لألى

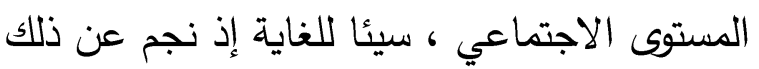
تعميق الطبقية في إسرائيل، التى كانت قائمة

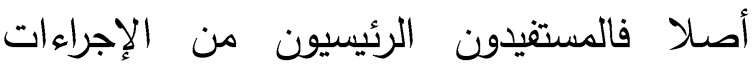
الجديدة، هم أصحاب رؤوس الأموال، الذين جنوا لإنداء

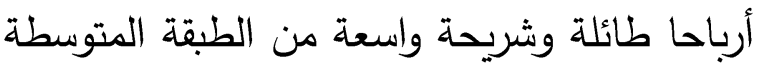
مكونة من ...- ... . ألف عائلة تملك عقارات تتراوح قيمتها، بين ربع ونصف مليون ليرة للعائلة • وازداد وضع الطبقة الفقيرة المكونة من العمال

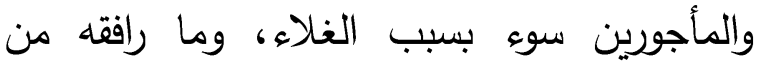
خفض في الإعانات، الميزانيات الاجتماعية. واستمر التحول نحو نظام الحكم الاقتصادي النيو -ليبرالي وتسارع هذا التحول ، أثناء الولاية النائ

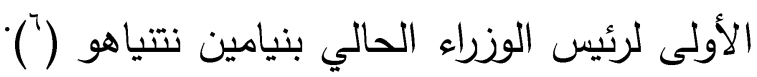

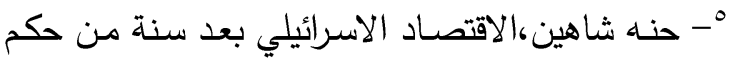

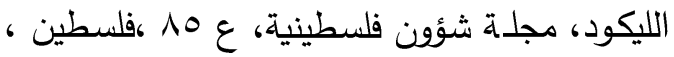
99 ص. 1971 " - شمعون، بيخلر ، ويائير نيتسان، ا. . ب. " رأس المال

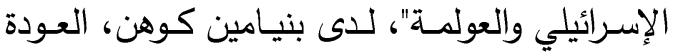

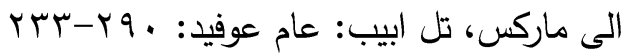

1910 على أنه نقطة التحول من اقتصاد إسرائيلي ذي مميزات اشتراكية، إلى اقتصاد ذي مميزات ليبرالية رأسمالية (ّ) ولكن يعتبر العام 9VV ام هو العام الذي شهد البداية الحقيقية للتحول التاريخي للاقتصاد الإسرائيلي، وهو العام الذي شهد فوز حزب الليكود اليميني وتفوقه على حزب العمل في انتخابات عام 9VV ام، حيث وعد الليكود بسياسة اقتصادية مغايرة عن السياسة التي انتهجها حزب العمل، وهي سياسة مرتكزة على التحرر الاقتصادي وتشجع الخصخصة، كما تهدف إلى تشجيع السوق الحر وتقليص دور الدولة بالحياة

الاقتصادية (ई).

وضعت حكومة ليكود، بعد تسلمها الحكم بفترة قصيرة ، أسسا اقتصادية جديدة في إسرائيل، تختلف كثيراعن السياسات الاقتصادية السابقة التى اتبعنها حكومات المعراخ (المعراخ هو تجمع حزبي إسرائيلي تثكل نتيجة اتحاد حزب العمل الإسرائيلي مع حزب مبام عام 1979 وأمسك

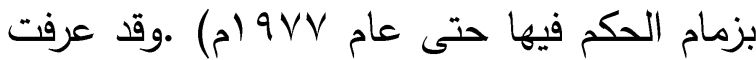
هذه الأسس باسم "السياسة الاقتصادية الليبرالية "، والتي أعلنتها الحكومة الإسرائيلية فى أواخر

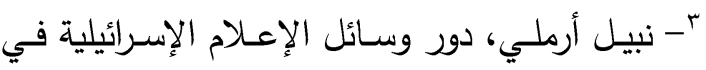
الترويج للفكر الاقتصـادي النيو - لييراي ، تاريخ الإيخ r. $1 \mathrm{H} / \cdot \mathrm{r} / \mathrm{MA}:$ النش agCR 9 HYhttps://bit.ly/ ؛- د. حسام جري، الاقتصاد الإسرائيلي: النشأة، البنية،

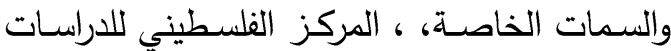

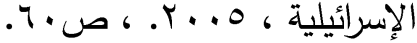




\section{الاحتجاج على النيوليبرالية الاقتصادية في}

إسرائيل

نتيجة للآثارالسلبية التى خلفتها السياسة

النيوليبرالية المتوحشة ،على الطبقة الوسطى في إسرائيل وزيادة نسبة الفقر والبطالة ،شهدت إسرائيل منذ أواسط يوليو الب م م ، حركة احتجاج اجتماعية غير مسبوقة، من حيث حجمها و استمراريتها، ومن حيث نوعية القوى المشاركة فيها (·) ، وابتدأت حركة الاحتجاج بنصب الخيام في أحد الميادين الرئيسية في تل أبيب احتجاجا على غلاء أسعار الثقق، سواء للشراء أو أو الاستئجار؛ وما لبثت أن انتشرت الخيام في ميادين المدن والبلدات الإسرائيلية الأخرى، ليصل عددها إلى سمسب خيمة ('"). لم يكن هناك أفضل من هذا التاريخ الرمزي لاختياره لانطلاقة الاحتجاج الاجتماعي، والذي أطلق عليه اسم "احتجاج الطبقة الوسطى". ففي لهي هذا اليوم من العام VA9 ام سيطرت الجماهير الباريسية على "الباستيل" معلنة أن (الطبقة الثالثة) (الطبقة الوسطى) هي الشعب الفرنسي (rا') .

' '- أمطانس شحادة ، صيف إسرائيلي ساخن ، مجلة

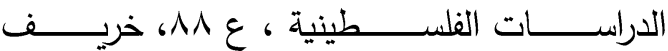

$$
r \cdot \varepsilon \text { • }
$$

ו- אמיר ארן • " המשטרה מתכוננת לפנות את

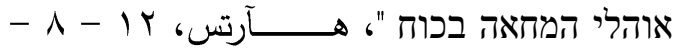
$.4 \cdot 11$

http://www.haaretz.co.il/hasite/objects/pages/P rintArticle.jhtml?itemNo=1237896

- דני פילק،אורי רם ، עלייתה ונפילתה של 12 המחאה החברתית (עד כה) ניתוח סוציו -
حيث وضعت حكومة نتنياهو الأولى 999 1999 (م، نصب عينها هدف خفض التضخم المالي من \% 1 إلى ب \% وخفض العجزالمالي في ميزانية الحكومة، وتحريرقطاع العملة الأجنبية، وخصخصة القطاع العام، وفتح المنافسة في سوق الاتصـالات (v) واستمرارا لنفس النهج، وضعت حكومة ايهود باراك 999 1-1 + . ب أهداف تطويرالاقتصساد وفقا لمبادئ الاقتصاد الحر-اقتصـاد السوق المتوازيـة، بهدف زيادة المصادر المتاحة للدولة، واستغلالها بشكل يساهم في تطويرالاقتصاد، على رأس سلم اهتمامها الاقتصادي (^). وتفاقمت دون أي رادع حين شغل نتتياهو منصب وزير المالية في حكومة شارون في الفترة

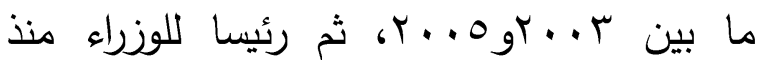
مارس 9 . . + م وحتى اليوم. حيث يعتبر نتتياهو من أشد ، المتحمسين بل من رموز المنهج النيو ليبرالي ، وهو أحد القادة الكبار القلائل المتميز بكون أعماله "مشتقه من فلسفته، يعلن أنه سيقلص مصاريف الحكومة من دافع فلسفة يؤمن بها وليس من دافع الضرورة"(9).

$$
\text { V - الموقع الرسمي لمكتب رئيس الحكومة: }
$$
http://www.pmo.gov.il/History/PastGovernments/Do cuments/: part27.pdf

r- الموقع الرسمي لمكتب رئيس الحكومة: http://www.pmo.gov.il/History/PastGovernments/Do cuments/ : part30.pdf 9 - د.حسـام جـريس، المشـهـ الاقتصـادي ،تقريـر مـدار الاستراتيجي • ( • بمدار كرام الله صبr •r 
وعلاقاتهم مع الإعلام والجماهير لكسب اهتمام

جماهيري كبير، الأمر الذي تطور إلى موجة

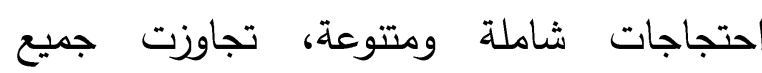

$$
\text { التحضيرات الأولية (ء) (). }
$$

وكان تعبير "ملح الأرض" هو الأكثر وضوحا الأل

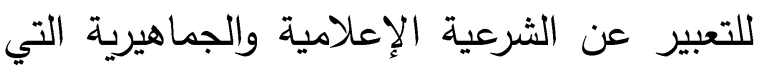
حظيت بها الاحتجاجات، وهو التعبير الذي يؤهل هؤلاء الثبان لطرح مطالبهم باسم الجيل الثاني

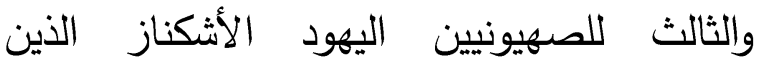
يخدمون في الجيش، ويدفعون الضرائب وبعبارة أخرى وفق المصطلحات الصهيونية "دفعوا قسطهم لللدولة". وحقهم في الاحتجاج، بناء على التوجه الصهيوني التوافقي، لاينبع من حقوق ديمقراطية أو اجتماعية ، بل من العقد القائم بني المواطن

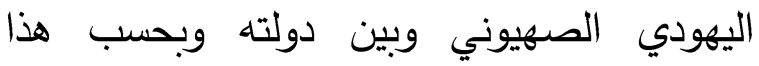
العقد، على المواطن أن "يخدم الدولة" وبالكقابل توفر له الدولة ظروف معيشية معقولة، وتعاملا منصفا كمواطن من الدرجة الأولى، وفرصة للحصول على التعليم وعلى عمل يعيله ويمكنه

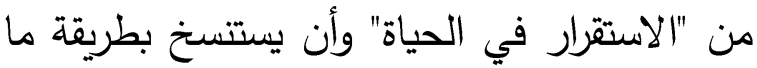

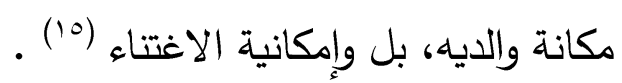
وأدت سياسة نتتياهو الاقتصادية النيولييرالية

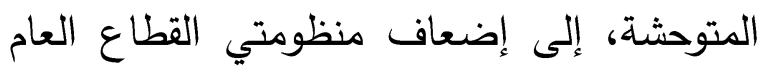

ـ ا- خيراردو لايبنر ، فصل الصيف الإسرائيلي الذي

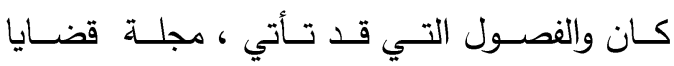

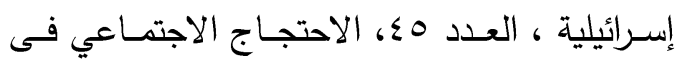

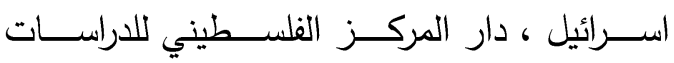

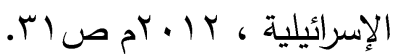

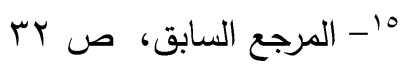

بدأت موجة الاحتجاجات عندما دشنت شابة إسرائيلية تدعى "دفنى ليف" صفحة عبر حسابها

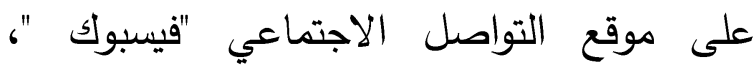
للاحتجاج على ارتفاع أسعار منتجات الألبان، الأمر الذي تفاعل معه عدد كبير من الثباب الثاب التبان ،المتضررين من ارتفاع الأسعار في إسرائيل .

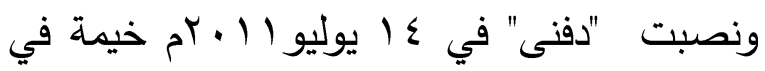
ميدان روتثيلد في وسط تل أبيب . وكانت خيمة "دفنى " بمثابة الشرارة الأولى التي في لتي اندلعت منها موجة الاحتجاج وخلال أيام معدودة

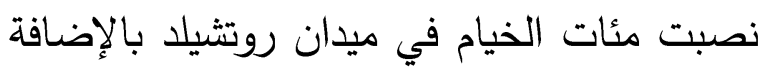
إلى آلاف الخيام في جميع أنحاء إسرائيل . وخلال أسبوع واحد فقط ، اندلعت مظاهرة، شارك الع الحكاء

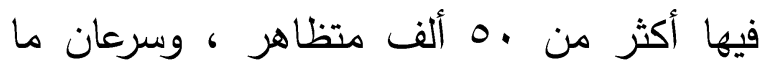
أستبدلت الشعارات المنددة بارتفاع أسعار السكن اهن

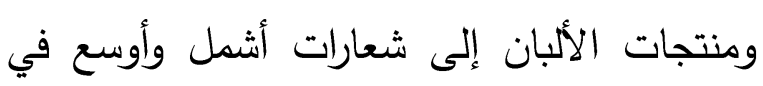
مفهومها الإقتصادي مثل "الشعب يريد عدالة التئ

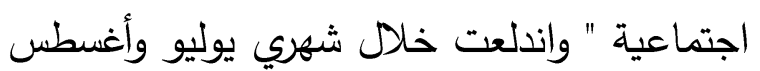

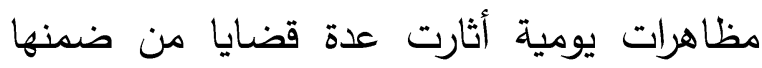
التعليم وتكاليف المعيشة وإصلاح قطاع العقارات

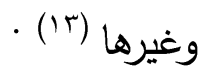

ونجح الثباب الإسرائيلي الذي ينتمي أغلبيتهم

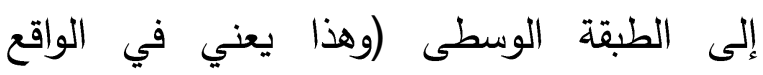
الاجتماعي الإسرائيلي أن أغلبيتهم الساحقة من أصول يهودية أشكنازية) في تسخير مهاراتهر الأيتر

פוליטי ، תיאוריה וביקורת ، גיליון41، מכון

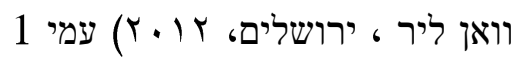

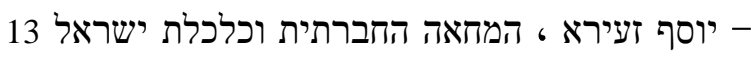

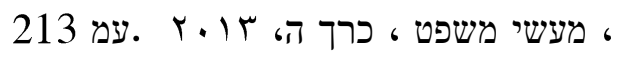


أصدر ناشطون إسرائيليون كتابا جمعوا فيه القصائد الملقاة في الاحتجاجات هناك، وهي قصائد ذات بعد طبقي وسياسي واضح. وتعد استكمالا لمجموعتين شعريتين أصدرتهما نفس المجموعة من النشطاء والثعراء، وهما " حمراء

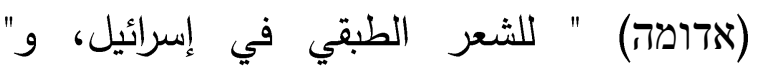
اخرجوا(לצאת) " للقصائد الرافضة للحرب على إنى غزة. كتاب "ديوان الثورة: أشعار الخيام"، حرره كل من يوديت شحر، روني هيرش، يعرا شحوري،

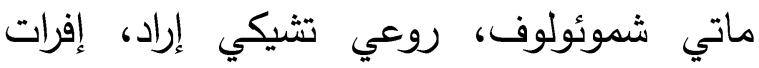
ميشوري، يهوشواع سيمون وغيرهم. ويضم قصائد من كافة أنحاء العالم، بالإضافة إلى الأثنعار

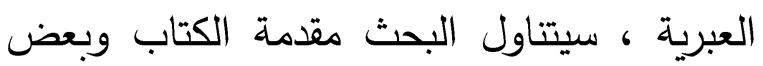
القصائد للإيضاح مدى تأثير السياسة الاقتصادي على الوضع الاجتماعي هناك. 1 ـ تمجيد ثورة الخيام ضد فساد السلطة الوضاعة ארז ביטון

ايريز بيطون لأن كل خيمة في ميدان روتثيلد כי כל אוהל בשדרות רוטשילה העיל هي مثال صغير للجمال הוא הצהרה קטנה של יופי والقوة של עוז רוח وإمكانية كبيرة של סיכוי גדול لقلب الأمور رأسا على عقب להפוך קערה על פיה وتقديم رؤساء المدن والمسؤولين להעמיד את ראשי העיר ואת ראשי הממשל לחמיד
والاتحادات العمالية. وإلى خروج الفرد المتوسط من

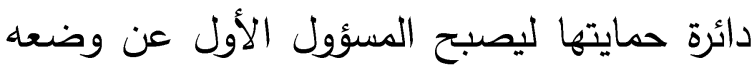
الاقتصادي الآن وفي المستقبل. فقي إطار

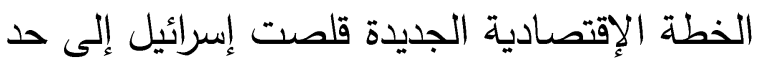
بعيد خدمات الرفاه والرعاية الاجتماعية للمواطنين ونقلت هذه المسؤولية إلى الأفراد أنفسهم (T'). وكذلك خصخصة الخذمات الاجتماعية، وتآكل دولة الرفاه وسياسات الضرائب ،مما ترك آثاره المختلفة على شرائح المجتمع فاستفادت بالدرجة الأولى الطبقة العليا وتحديدا رؤوس الأموال وكبار رجال الأعمال الذين يطلق عليهم في إسرائيل

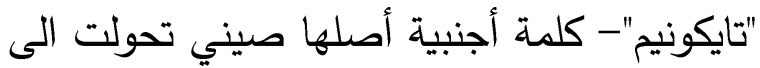
الانجليزية عبر اليابانية - وتضررت بشكل واضح الطبقات الفقيرة ،والطبقة الوسطى، التي لإني

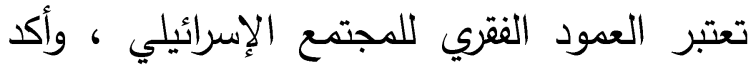
المسح الاجتماعي الصادر عن مكتب الإحصاء المركزي الإسرائيلي على أن الفجوة الاجتماعية تتسع وتسفر على إبقاء إسرائيل في أعلى نسب الإنب الإني

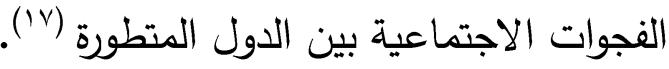

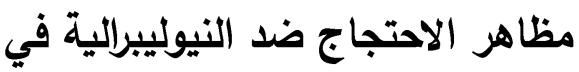
المجموعة الثعرية ديوان الثورة "أثعار الخيام" שירון המהפכה "שירת האוהלים"

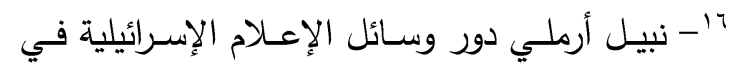
الترويج للفكر الاقتصـادي النيو - لييرالي ، تاريخ الإيخ النشر: النش

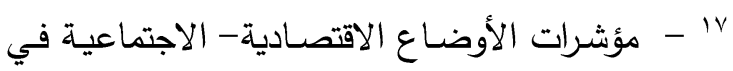

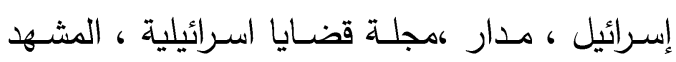

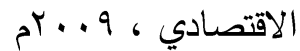


ושטעבורם העם הוא רק

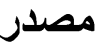

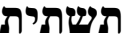

لمبن الكبير

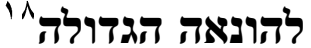

يسرد الشاعر "ايرز بيطون"(9') في هذه القصيدة أسباب القيام بحركة الاحتجاج الإسرائيلية في العام 11 إم ،حيث يبدأ القصيدة بحرف " لأن" الذي يفيد التعليل وكأنه ردا على سؤال ، لماذا

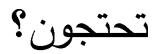
ويبدأ فى توضيح الأسباب التي ساقتهم للاحتجاج ومنها احتمالية قلب الأمور رأسا على عقب المسؤولين وتقديم مسؤولي الحكومة للعدالة بسبب القضاء على أمال المواطن الإسرائيلي. واستخدم "بيطون" كلمات مثل "قطع شطرنج" و"نفايات عضوية" للتعبير عن مدى الظلم الذى يمارسه المسؤولون فى اسرائيل ضد المواطن،

ג'- שירון המהפכה' שירת האוהלים. ערב רב . אתגר.גרילה תרבות.2011 19 - ايريز بيطون: ولد في مدينـة وهران في الجزائر،

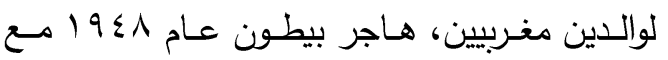

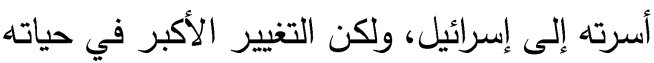
حدث بعد مرور نحو ثلاثة أعوام، عندما فقد بصره وقطعت يده لدى إصابته بعبوة ناسفة وضعت قرب لمربه

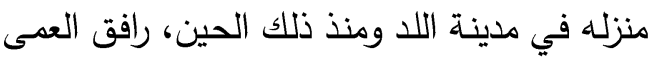
حياة بيطون ـ تعلم بيطون العمل الاجتماعي وعلم

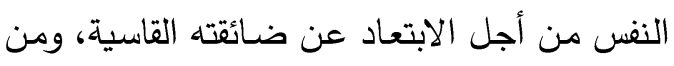
أجلـل الخـروج مـن دور الضـحية والـدخول في دور

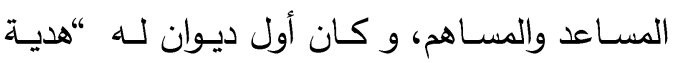
مغربية" بعد ذلك أصدر بيطون أربعة دواوين شعرية وله ولية أخرى، والتي حظيت بالكثير من المعجبين.
للمحاكمة والعدالة לדין ולצדק لأنهم تعاملوا معنا على أنتا بلا عقل وأستخدمونا كقطع شطرنج כי השתמשו בנו כצטולי דעת וכחיילי שיחטים وقضوا على آمالنا לחסל את תקוותנו وكلنا فردا فردا

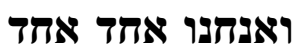
عالم بأكمله من القوة والحياه פולם ומלואו של כוח וחיים فلتسقط السلطة الخسيسة والمستغلة والإستقوائية

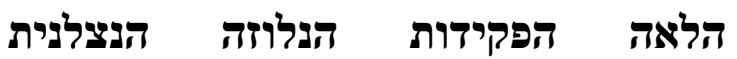

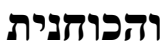

التي تدافع عن نفسها بوضع حراس عند كل باب

הצגנה פל עציםה בידי שומרים על כל פתח

فليسقط الاستغلال الااعر الأي يمارسه محبو السيبار הלאה הניצול הציפי של אוהבי הסיגרים

$$
\text { הנשרפים בכיסים في الجيوب }
$$

والأين يقيمون في الأجنحة الفاخرة داخل إسرائيل وخارجها

והלנים בסוויטות החשק בארץ ובחו"ל الأين يرون في الشعب مجرد نفايات عضويـة שעבורם העם הוא רק זבל אורגני ومصدرا لإشباع شهواتهم תשתית ליצרים שלהם الأين يرون في الشعب مجرد 
تتخلى عن دعمها للمواطن وتركه فريسة لسياسات اقتصادية مجحفة.

ويلقى "بيطون" الضوء أيضا على رعاية الدولة لطبقة كبار رؤوس الأموال على حساب الطبقة الوسطى ، وتعتبر طبقة رؤوس الأموال الأكثر استفادة من سياسة اقتصاد السوق الحرة، وتذل المؤشرات كلها على أن الفئات الغنية في المجتمع الإسرائيلي حققت نموا متسارعا في دخلها على حساب الفئات الفقيرة (rr) ، حيث أظهر تقرير مركز "أدفا" للأبحاث الاجتماعية الاقتصادية أن العقد الأخير شهد تراجعا في المساواة والعدالة الاجتماعية في إسرائيل، مؤكدا أن ثمار النمو لم تتوزع بشكل متساو، وأشار التقرير إلى تقلص الطبقة الوسطى من سr\% في العام 1991 إلى

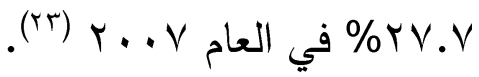
وألقى الشاعر الضوء على بعض قضايا الفساد من خلال استخدام بعض الالفاظ مثل والأين يقيمون في الأجنحة الفاخرة داخل إسرائيل وخارجها) ويقصد بها قضية عرفت باسم (بيبي تورز) وتتعلق القضية بقيام رجال أعمال بتمويل رحلات طيران نتانياهو وزوجته سارة للخارج وأيضا التكفل بنفقات الإقامة بالفنادق الفاخرة فى وروله

rr - فضـل النقيب، الاقتصـاد إلاسرائيلي، دليل إسرائيل العام 11 + ب، مؤسسة الدراسات الفلسطينية، رام الله

$$
\text { ( }
$$

rr - إمطـانس شـحادة، حركـة الاحتجـاج الإسـرائيلية مـن منظور اقتصادي سياسي، المركز العربي للأبحاث ودراسة السياسات، ،موقع عرب ^^ ، تاريخ النشر :

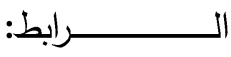
l. $r .11 / .9 / 1 r$ https://www.arab48.com
ممجدا في الوقت نفسه خيمات الاحتجاج والمتظاهرين - و وميدان روتشيلد من أكبر ميادين تل ابيب وتعود تسميته بهذا الاسم الى إدموند جيمس دى

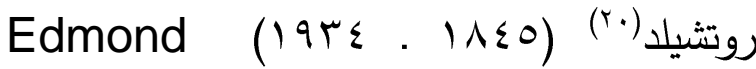
، Benjamin James de Rothschild الاقتصادي ورجل الأعمال اليهودي ، وأهم المشاركين في تتمية المشروعات الاستيطانية اليهودية في فلسطين (r). ولم يكن هناك أفضل من اختيار هذا الميدان لانطلاق أكبر احتجاجات اسرائيلية لرفض الارتفاع الجنونى لأسعار المساكن في إسرائيل فكيف لدولة قامت في الأساس على تشجيع اليهود للهجرة وتوفير المستوطنات اللازمة للسكن أن •r - إدموند جيمس روتثيلد :هو أحد أفراد أسرة روتثيلد،

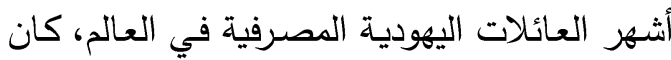

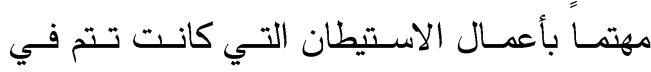
فلسـطين علـي يـد حركـة أحبـاء صـهيون ، وقـام بدعمها عن طريق المنح المالية ، ومساهته الكبيرة

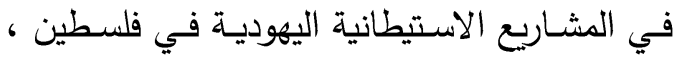

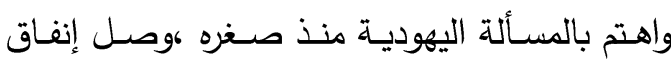
إدمونـــــيمس روتثـيلد على المسـتوطنين خـلال الفتـرة (

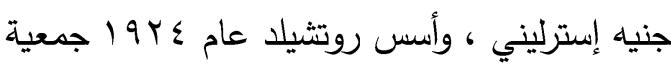
الاستيطان اليهودي في فلسطين. وفي عام 9 و 19 عين رئيسا فخريا للوكالة اليهودية ـ ولولا مساعداته

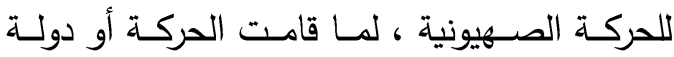
https://www.al-masdar.net. إسرائيل

'ז'- לקסיקון אישים ומונחים، רוטשילד، הברון בנימין אדמונד דה (1845-1934) https://main.knesset.gov.il/About/Lexicon/Pages/rotc hild_ad.aspx 
الأسباب وراء ذلك، فعلى الرغم من أن معدل دخل

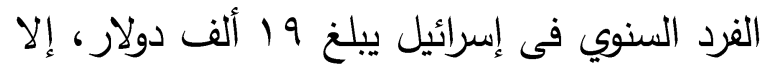
أن معظم الثباب الإسرائيلي العامل والحاصل

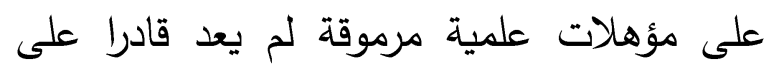
شراء شقة سكنية، حيث بلغ متوسط سعر الثقة السكنية . . r ألف دولار (ror). ولم يستطع الأدباء الإسرائيليون الذين شاركو في احتجاجات الخيام

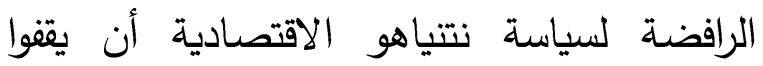

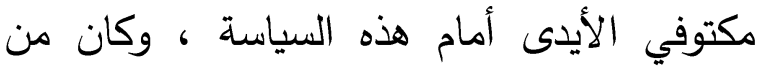

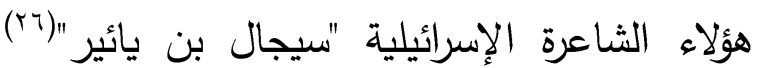
فقد كتبت قصيدة بعنوان "قصيدة بيتين مؤجرين" تقول فيها :

שיר בששפי בתים שכורים

قصيدة بيتين مؤجرين

סיגל בן יאיר

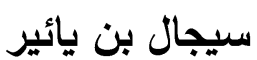

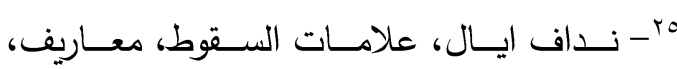

$$
.11 / 2 / 19
$$

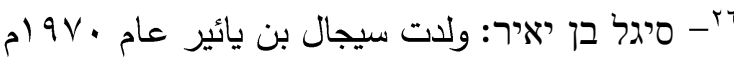

بحيفا ،تخرجت من من جامعة حيفا درست الادب

العبـري المقـارن ، نشـرت بـن يـائير خـلال العقدـ

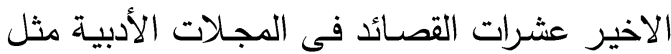

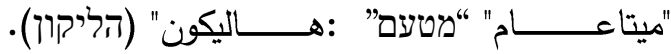

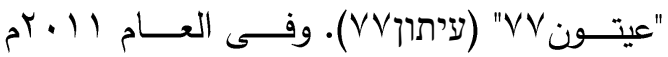

أصـدرت ديوانهـا الأول "غير مكرر"( לא מעודן). לקסיקון ביו־ביבליוגראפי של הספרות העברית

$$
\text { החדשה : }
$$

https://library.osu.edu/projects/hebrewlexicon/02083.php
عدة دول خاصة فى الفترة التى تولى فيها نتتياهو منصب وزير المالية وعضو كنيست فى الفترة من

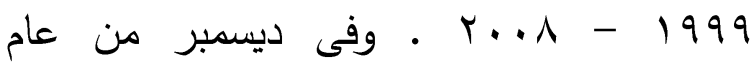
r 1 • rم، أرسل مراقب عام الدولة كافة المستتدات والوثائق التى جمعها حول هذه القضية إلى المدعى العام. وكثفت القناة العاشرة بالتليفزيون الإسرائيلى أن وحدة مكافحة جرائم الفساد بالثرطة الإسرائيلية بدأت التحقيق مع بعض المقربين من نيتانياهو الذين عملوا معه عن قرب فى وظائف مختلفة كى تعرف من خلال أقوالهم أسماء ممولى ملى رحلات أسرة نتانياهو وفى سبتمبر ع ا • بم، قرر المستشار القانونى للحكومة الإسرائيلية يهودا فاينشطاين إغلاق ملف هذه القضية ضد نتانياهو بحجة أن ما تم جمعه من أدلة لا يستوجب إدانته جنائيا • وفى يناير 10 • بم ،فجرت القضية مرة أخرى، عندما قدم عضو الكنيست عن المعسكر الصهيونى، ميكى روزنطال دعوى قضائية لإلغاء قرار المستثار القانونى للحكومة بعدم فتح تحقيق جنائى ضد رئيس الوزراء الإسرائيلى فى قضية

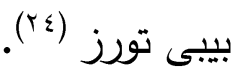
r ـ الاحتجاج على غلاء أسعار المساكن فى لورج إسرائيل مما لا شك فيه أن قطاع العقارات كان الأكثر تضررا من سياسة نتنياهو الاقتصادية، وكان الارتفاع الثديد فى أسعار الأراضي، من أهم

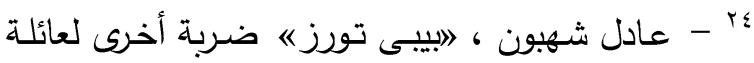

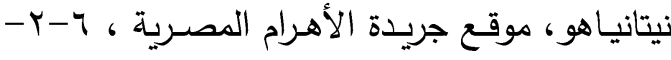

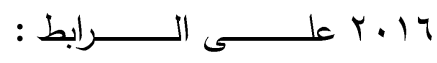
http://www.ahram.org.eg/News/131808/115/47 5015 
הסובא، הזולל، מרייר، לועם، חוצס פוטף נוטף זיעה נוטף بقعة زبت من شطيرة تونة

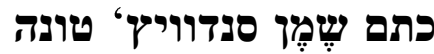
تشربتها الصفحات كالبصمة נספג לאט בין הדפים כמו טביצת חותם.

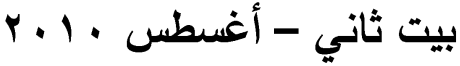

$$
\begin{aligned}
& \text { בית שפי - אוגוסט } 2010
\end{aligned}
$$$$
\text { انا الإنسان العابر،الفوق - زمني، الغزيب }
$$

אפי האדם הארצי، העל-זמצי، הזר

في بيته، الغربب عن حوائطه يحزم أمتعته

$$
\text { ويفرغها }
$$

בביתו، הזר לקירותיו האורז ופורק

ويفرغها دون أسم محدد وعنوان يمكن الوصول

ומפרק، ללא שפ קבוע וכתובת אחרוצה למעצבר

أنا الإنسان المتأمل في زوايا المشاهد المتغيرة التى أراها من كل ناقذة

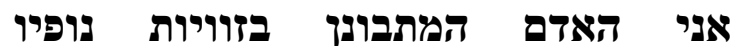

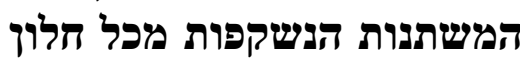
الأي يخطى بين غرفه اليمنى واليسرى התופה ביץ חדריו הימפיים לשימאליים גופים في قلب التلا بيت. أنا الإنسان الخائف من أصوات الليل

של לב האין-בית. אפי האדם החרד לקולות הלילה الجديدة ،الأي يدفن، أمتعته في كتل الأسمنت החדשים، הטומן את חפציו במלט

$$
\text { البيت الأول - أغسطس } 9
$$$$
\text { בית ראשון - אוגוסט } 2009
$$

يتمعن المحامي السمين في قسائم مرتبات

$$
\text { الثلاثة شهور الأخيرة }
$$

פורך הדין הששמן מתבופן בשלושתת תלושים ועפים

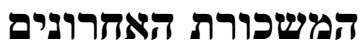

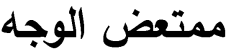
מושך באפו. ربما أعتذر، ربما أتوسل، أو أطلب العفو والسماح

אולי אתפצלי או אתחפף، או אבקש מחילה أشتري إيصالا، وأمضى عليه، وألتزم، وأمضي

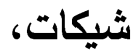

אקנה שטרל אחתים6 אתחייב, ארשום

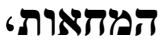

أخطىء ، وأمضي شيكا آخر، وأوقع ،وأنتظر الموافقة

אטעה، ארשום המחאה פוספת، אחתום. אמתין לִִישור أحضر ضامنين ،وأوقع ثانية، بالأحرف الأولى ،وبأحرف صغيرة אביא עּרבים، אחתום שובי בראשי תיבות، באותיות קטנות أقدم تنازلات، أتوصل لحلول وبط ،لا أنقض، ألتزم مرة أخرى للمحامي السمين אוותרי אתפשר، לא אפר، אתחייב בשפית לעורך הדיץ השי מין الأي يعب في شرب الخمر ،الأكول ،الأي يتمخط ،الأي يلوك ،ويتصبب عرقا 
وفي تلك الأثناء تبدأ الشاعرة في نقل خواطر المستأجر الذي يتحدث مع نفسه ، والذي تتنابه مشاعر الحيرة والخوف من رفض المحامي تأجير المسكن له ، وقد اختارت "يائير" بعض المفردات

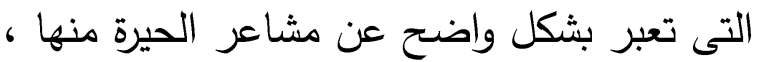

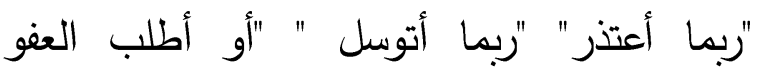
والسماح" • ثم تنتقل بعد ذلك إلي وصف هذا

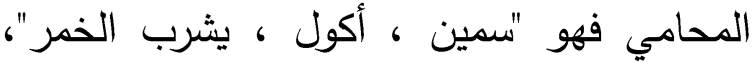
وكلها إشارات إلى حالة النهم التى تتصف بها لهان طبقة الأغنياء متمثلة في ذلك المحامي من وجهة الفارك

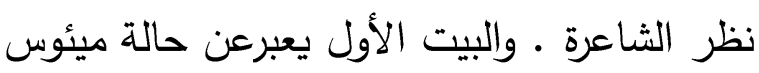

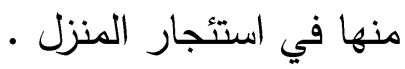
وبما أن الشعر لا يعيد انتاج الواقع فقط، بل يبتكر ويخلق عالما آخر بديلا تحسه الرؤيا الثعرية وكل شعر وفن عموما هو فى معناه الجوهري احتجاج على الواقع القائم^^، ،فقد نقلت الثاعرة

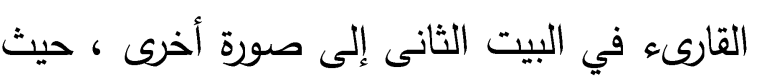

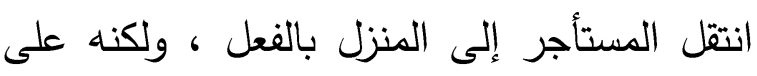

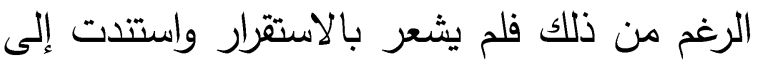

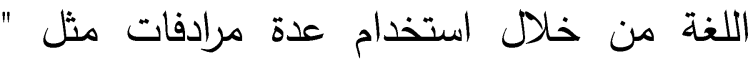
الغريب " "التائه" "الخائف" "فاقد الذاكرة" وكلها كلمات تعبر عن مدى شعور المستأجر بالغربة وعدم الاحساس بالراحة في هذا المنزل لعدم لعند

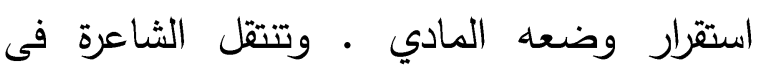

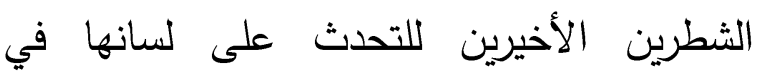

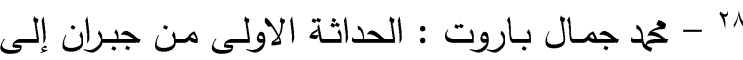

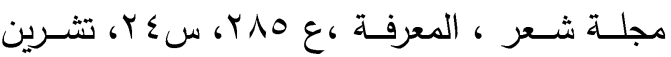

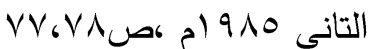

أنا الإنسان فاقد الذاكرة، الراحل بلا عودة ، אני האדם הלא-זוכר، האל-חוזרם الدافن ذكرياته في السلوان الكئيب הקובר את זכרונותיו בנחמה הקודרת الذي يسير عكس الطريق

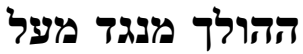
، ويحولّه للا شىء

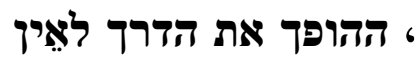

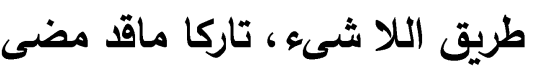
דרך להין זוכר، מוותר أهيم في النسيان مثل جناح عصفور محلق ،هانىع في الظلام، הצף בשכחה כמו כנף ציפור בדאייה، של ווה בחשיכה،

أنا الإنسان المتنازل عن كل ماكان ومالم يكن

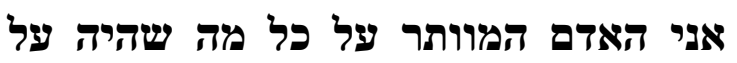
כל מה שאין أنا لأحلم ـ يقظة في نومي .أرفض العزاء. אינפי חולמת. ערה בשנתי. מסרבת להיוּחם. ליני

بدأت الثاعرة "سيجال بن يائير" قصيدتها بوصف مشهد يجمع بين "الهحامى" الذي يرمز

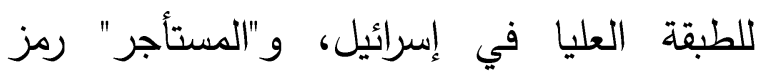
الطبقة الوسطى أو الكادحة ، فالمحامي ينظر إلى ولى

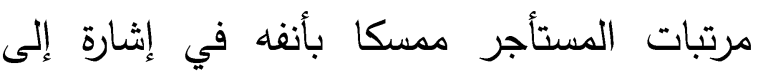
غضبه - ربما بسبب مرتب المستأجر الضئيل-

V' - שירון המהפכה' שירת האוהלים. ערב רב . אתגר.גרילה תרבות.2011 


$$
\begin{aligned}
& \text { غرفتان } \\
& \text { שפי חדרים } \\
& \text { وظيفتان } \\
& \text { ששתי משרות } \\
& \text { وحسابين - وحسי } \\
& \text { ושפי חשבופות - ושית } \\
& \text { كلاهما بالدين، } \\
& \text { בשפיהם בחובה , }
\end{aligned}
$$

وأملك ميراثًا وأملك خصائص وراثية

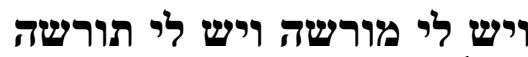
وأجرا عن التدريس يغطيني بالكاد. ומשכורת הוראה שבקושי מכסה

خمسمائة ليرة لا أملكها، يا فرجينيا חמש מאות לירות אין לים וירג'יפיה ولا أملك غرفة تخصني،

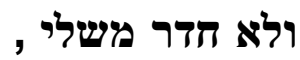
لاي قلم وورقة ישי לי צט ועייר ورغبة مكبوتة ותששוקה שתתוקה משתים ونور شاحب ينساب على استحياء ואור חיוור שנוהר בשתיקה عبر نافذة צבעד חלוץ نصفها مغلقة דציו סגור

\section{ونصفها مفتوحة على مصرعيها} חציו פעור לרווחה. وهنا تتحدث الثاعرة عن عدم قدرة قطاع كبير من المواطنين على شراء مسكن خاص بهم بسبب تدنى الأجور • وتعتبر سياسة نتياهو الاقتصادية هي السبب الرئيسي والمباشر حيث قلصت حكومة
محاولة منها للتعبير عن حالة اليأس التى تعيشها هى أيضا، مثلها مثل المستأجر مهر وفي قصيدة أخرى بعنوان " חדר משלי" "غرفة تخصني " للشاعرة יודית שחר "يوديت شحر" "ג" • تستتكر فيها الثاعرة عدم قدرة مدرس على شراء شقة تخصسه وتقول فيها:

\section{חדר עשים}

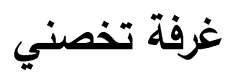
יודית ששחר

$$
\text { يوديت شحر }
$$

لا أملك خمسمائة ليرة*، يا فرجينيا אין לי חמש מאות לירותם וירג'יניה ولا أملك غرفة تخصني،

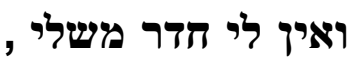

لي طفلان ישי לי שפי ילדים
9'- יודית שחר: ولـدت عـام 909 ام فـي اسـرائيل

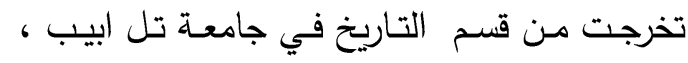
متخصصـة في كتابة الثـعر السياسي والاجتمـاعي . حـاز ديوانها "זו אני מדברת" (هذه أنـا أتحدث) بجــائزة "טבע לשירה" عـــام 9. +. זم • לקסיקון הספרות העברית החדשה יודית שחר (1959) • https://library.osu.edu/projects/hebrew- 6 lexicon/01720.php * ليرة إسرائيلية (بالعبريـة: לירה ישראלית) وهي العملة

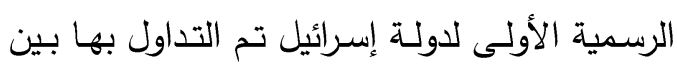

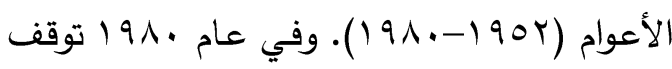

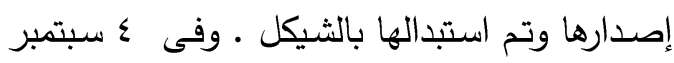

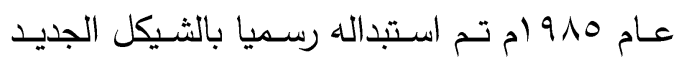
وذلك كجزء مـن خطـة الاستقرار الاقتصـادي لعـام 
(Tr ) . . وهنا استخدمت "يوديت بن شحر" التضاد

للتعبير عن وجهة نظرها وإبراز قضيتها وهما

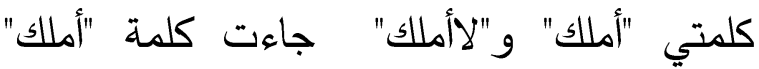
مصاحبة لبعض الكلمات مثل " طفلين" و "شفرة وراثية" "قلم وورقة " "أجرا عن التدريس" أما كلمة "لا أملك" فجاءت مصاحبة للفظ المال. وهذا كناية عن عجز المواطن الإسرائيلي بالرغم من امتلاكه وظيفة ترمز للعلم إلا أنها تكفيه بالكاد ولا توفر له له بله

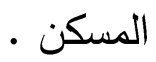
r - الاحتجاج على البيروقراطية والفساد فى الحصول على السكن الثعبي אנא איסמי זהבה ואיה

أنا اسمي زهافا أعيش في الحيز الايمقراطي،

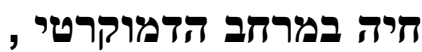
أموت في الحيز البيروقراطي.

מתה במרחב הבירוקראטי . يطردونتي من البيت. הם מסלקים אותי מהבית . ليس لايك مال لتدفعيه للفاسدين. אין לך כסף לשלם למושחתים . ليس لايك مال لتدفعيه للفاسدين إذن احزمي أغراضك. أصلا لم نحب أن يسكن هنا أغراب، אין לך כסף לשלם למושחתים אז ארזי את החפצים. במילא לא אסף אהבצו שגרים פה אוזים את מוזרים , امرأة وحيدة مع طفل، في شقة تملكها الدولة. سمحوا لك بالحياة هنا برغم أنك مختلفة،

rrr - يوسف الخال :محاولات فى تفهيم الثعر الحديث

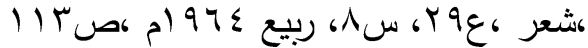

نتياهو دعمها للسلع، وبالتالى قلصت من قدرة

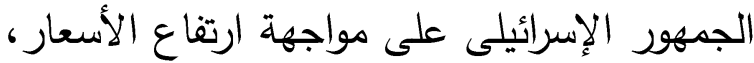
وكذلك قلصت الموازنة التى اعتمدتها الحكومات السابقة لمساعدة الأزواج الثباب على شراء شقق سكنية إلى حوالى ربع قيمتها، وتراجعت منذ العام

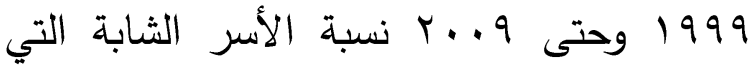
تمتلك مسكنا من إ \% \% إلى بـ ارتفعت أجور المنازل بنسبة عالية (r.). وأدى ارتفاع إيجارات الثقق إلى عجز جيل الثباب من شرائح واسعة من الطبقة الوسطى، ناهيك عن الثرائح الفقيرة، من شراء شقة لهم، فثمن شقة متوسطة في تل أبيب ارتفع في السنوات

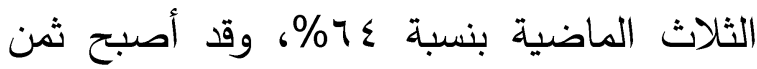
الثقة المتوسطة في تل أبيب يبلغ مجموع رواتب rع أشر للموظف من الطبقة الوسطى، وذلك

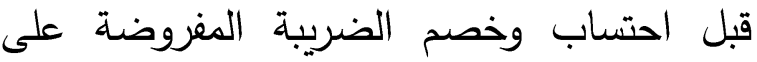
الراتب؛ أي ما يعادل مجموع دخل r I اسنة عمل، وما يقارب 17 سنة إذا تم احتساب وانتقاص

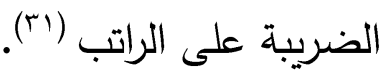
وتظهر عبقرية الثاعرة في القصيدة من خلال ما ماته تظهره من توانن وتوفيق بين الصفات المتضادة أو المتتافرة ، وفي الجمع بين التثابه والاختلاف لتفن

•-" דני פילק،אורי רם ، עלייתה ונפילתה של המחאה החברתית(עד כה) ניתוח סוציו -פוליטי

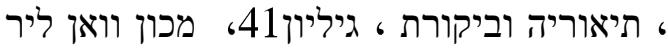

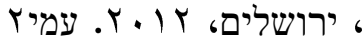

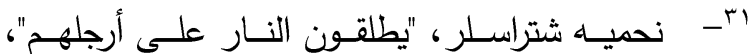

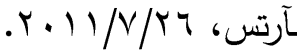

http://www.haaretz.co.il/hasite/objects/pages/P rintArticle.jhtml?itemNo=1236028 
لا تزال هناك نساء في الطريق. نساء جميلات جذا، يبدو عليهن الركل ، وآثره في الوجه، יש עוד נשים בשביל. נשים יפות פוראי עם כמה בעיטות ומשהו בפנים , פושים يحاربن هنا لأجل البيت، يسرن هنا منذ

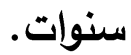
נלחמות פה על הבית، הן הולכות פה כבר שנים . إذن إذا اعتقدتم بعد كل هذه السنوات ربما

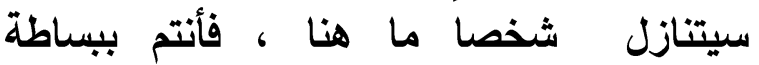
مخطئون، או אם אולי חשבתם שאחרי כל השינים מישהו מוותר פה، אתם פשוט טועים,

$$
\text { ولمن لم يسمع جيدا - نحن باقون! }
$$

ולמי שלא שמע טוב - אנחנו נשארים! في قصيدة " אנא איסמי זהבה" بدأت الثاعرة الإسرائيلية قصيدتها باستخدام عنوان " אנא איסמי זהבה" "أنا اسمي زهافا" باللغة العربية ولكنه مكتوب بحروف عبرية ، وهذا محاولة منها للكثف عن التمييز الذى تمارسه السلطة في إسرائيل ضد اليهود الثرقيين ، حيث أن غالبية أشعار يهود الشرق تتسم بالاهتمام الثديد بقضية التمييز الطائفي فى إسرائيل، وبأوضاع يهود الشرق في إسرائيل الذين يشعرون بالاغتراب،

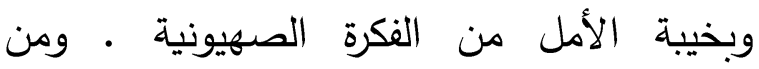
الملاحظ أيضا أنه تغلب على أشعارهم أيضا نزعة الأنة الحنين إلى أوطانهم التى ارتحلو عنها إلى إسرائيل

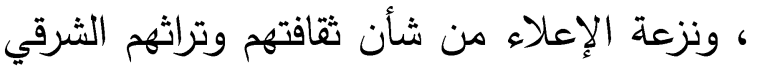
ونعتقد أن هذا الاعتزاز بأصولهم الشرقية والذى دئى

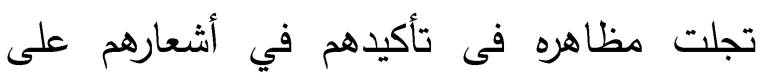

אשה לבד עם ילדי בדירה של המדינה.

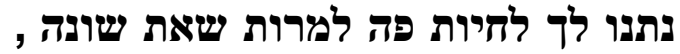
أنك دفعت بدون كلام وبدون السؤال عن

$$
\text { السبب؟ }
$$

ששילמת בלי לדבר ולא שאלת למה ? لقد أذوا روحي، أذوا نفسي، הם פוגעים לי בנפשי פוגעים בנשמה , وأنا أنقبض، أنتظر الموجة القادمة، ואני כבר מתכווצת، מחכה לגל הבא , ابني كبير، ابني ذكي. הבן שלי גזולי הבן שלי חכם . معك حق يا أمي، حاربي الجميع هنا. אמא את צודקת، תלחמי פה בכולם . لذا أبقى وأكتب رسائل. القاضية غاضبة: "لا تتحثي إلا إذا طلب منك". ואז אני נשארת וכותבת מכתבים. השופטת מתרגזת: “אל תדברי כשלא

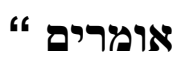
أنظف المكاتب: "ما الأخبار؟ كل شيء على ما يرام". للأشخاص اللطيفين. מנקה את המשרדים: "מה נשמעי הכול בסדר". לאנשים הנחמדים . אנים أنا اسمي زهافا، وربما متعبة قليلا אנא אִסמי זהבהי ואולי קצת עייפה لكن لأنتي ذاهبة فليس ثمة رجعة،

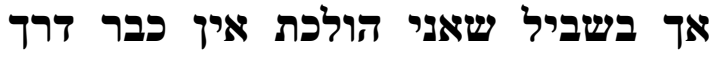

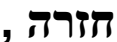
لذا أبقى ،مآراه - - ل ואז אני נשארת، ומה אני רואה - 
هويتهم الشرقية كان رد فعل طبيعي على كل وتحتج الثاعرة على الفساد خلال تعامل الجهات الحكومية مع المستحقين للاسكان الثعبي في لئي المحاولات التي تقوم بها السلطة الاشكنازية (rT)

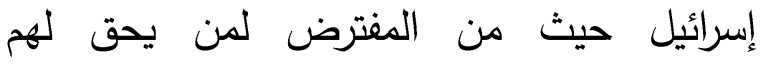

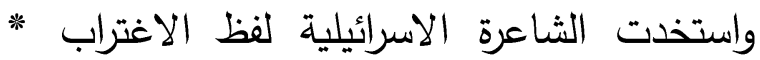

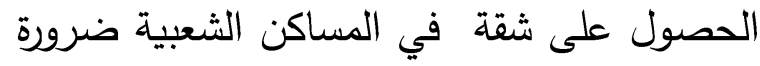

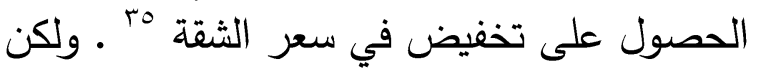
تكثف الثاعرة الاسرائيلية "زهافا جرينبيرج" الفساد

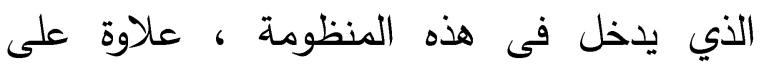

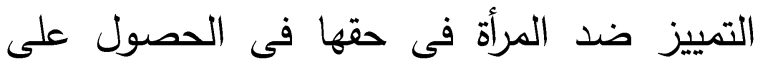

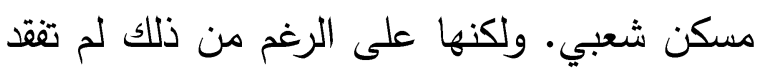

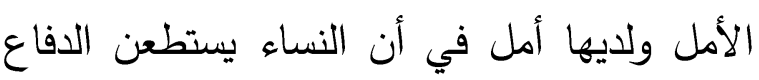

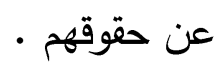
وتحتل إسرائيل المركز الثاني والثلاثين بين ونT دولة في مقياس تفشي الفساد، ويعني هذا أن ترتيب إسرائيل يأتي بعد الدول الصناعية الغنية،

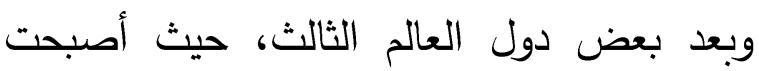
أخبار فضائح استغلال السلطة أخبارا عادية تغطى صفحات الجرائد بشكل يومي. فعلى سبيل

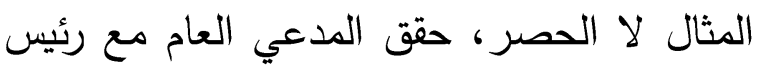

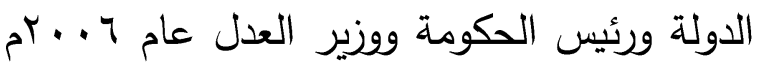

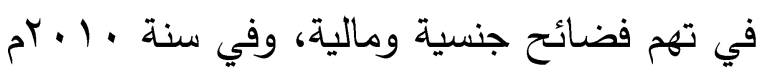

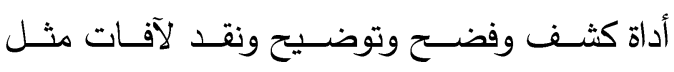

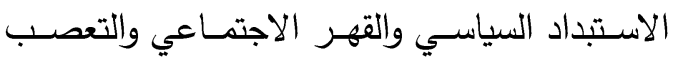

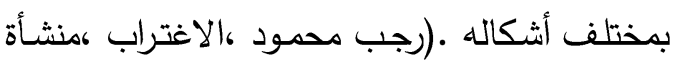

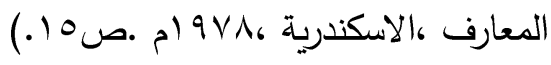
https://www.kolzchut.org.il/ar/ - ro للتعبير عن الحالة التى يعيشها اليهود الثرقيون في إسرائيل ، ويمكن القول أن الهوية اليهودية حينما انسلخت من البلاد التى عاشت فيها وسارت إلى الوهم الذي زينته لها الصهيونية بالحياه في إسرائيل في ظل الذات الإسرائيلية الجديدة ،فقدائه بالياه أصيبت بالاحباط التام بعدما تكثفت لها الأبعاد

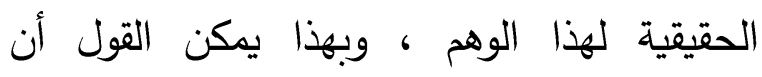
الثخصية اليهودية الاسرائيلية شعرت بالغربة والعزلة حينما انسلخت عن واقعها الاسرائيلي التى لتى لئه

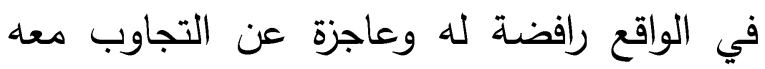
لأن هذا المجتمع لايملك أصلا المقومات التي لهن

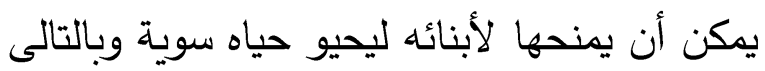

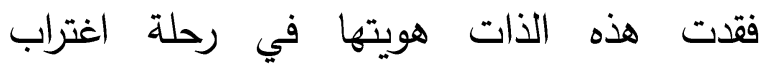
لانهائية (r) آنات

بrrr د.جمال أحمد الرفاعي ، إثكالية الاندماج الطائفي

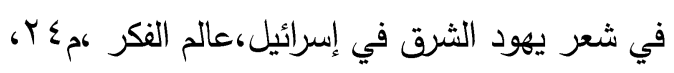

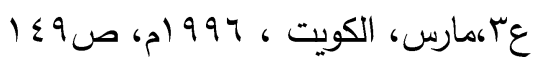

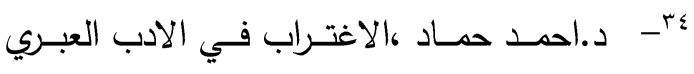

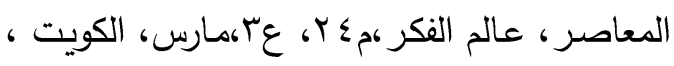

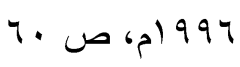
* الاغتراب هو مصطلح برز على سطح الحياة الثقافية العامـة في الاربعينيـات والخمسينيات مـن القـرن

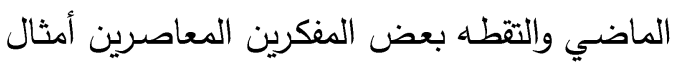
ماركيوز وفروم وغيرهما وهم أصحاب نزعة إنسانية إنسانية

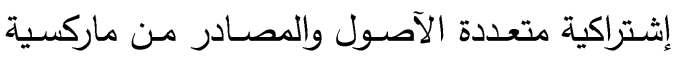
ووجودية وفرويدية وهيجيلية ـ ويرجع اليهم الفضل فيل فئل في في رواج هذا المصطلح في الغرب .وقد اتخذوه 
الذى أثر بالسلب على الطبقة الوسطى فى الولى اسرائيل ويادة نسبة الفقر.
أيضا حقق مع وزير الخارجية ومع رئيس حكومة سابق في تهم الفساد واستغلال النفوذ (Trا).

خاتقـة

تناول هذا البحث دراسة الاحتجاج على النيوليبرالية الاقتصادية في إسرائيل فى المجموعة

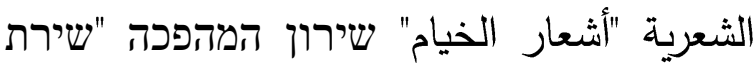

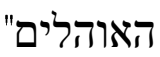
وعلى ضوء ماتقدم ، يمكن استخلاص النتائج التى تم التوصل إليها من خلال البحث في النقاط المصادروالمراجع أولا: المصادر

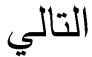

שירון המהפכה' שירת האוהלים. ערב רב. אתגר.גרילה תרבות.2011

\section{أخانيا : المراجع

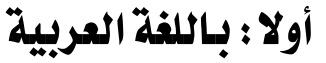 \\ أ ـ تقارير ودراسات}

1.أمطانس شحادة، ركة الاحتجاج الإسرائيلية من منظور اقتصادي سياسي،

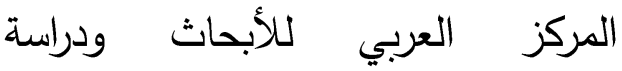

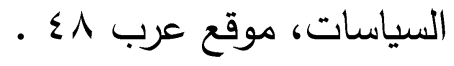
r.فضل النقيب، الاقتصاد إلاسرائيلي، دليل إسرائيل العام 11 إك، مؤسسة الدراسات الفلسطينية، رام الله.

$$
\text { ب ـ دوريات }
$$

ا.د.أحمد حماد، الاغتراب في الأدب

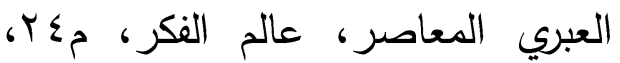

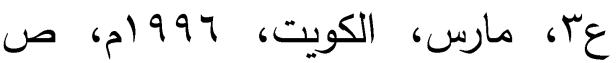

" يعتبر العام 9VV ام هو العام الذي شهد البداية الحقيقية للتحول التاريخي للاقتصاد الإسرائيلي، وهو العام الذي شهد فوز حزب الإبه الليكود اليميني وتفوقه على حزب العمل في انتخابات عام 9VV ام حيث وعد الليكود بسياسة اقتصادية مغايرة عن السياسة التي

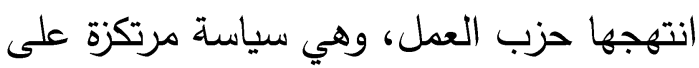
التحرر الاقتصادي وتثجع الخصخصة، كما تهاف إلى تثجيع السوق الحر وتقليص دور الدولة بالحياة الاقتصادية. • ترجع أسباب إندلاع حركة الإحتجاج الفادية. الاجتماعي التى إجتاحت إسرائيل فى العام

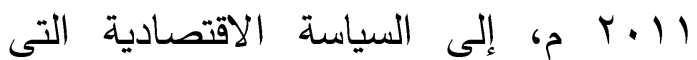
اتبعتها الحكومات الاسرائيلية الممتابعة فى العى لإلى العقود الاخيرة والتى تبنت الفكر النيولييرالي

rr"- - فضل النقيب، الاقتصاد إلاسرائيلي، دليل إسرائيل

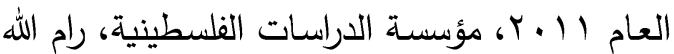
(1) 
ا ـ د. حسام جريس، الاقتصاد الإسرائيلي:

النشأة، البنية، والسمات الخاصة، المركز

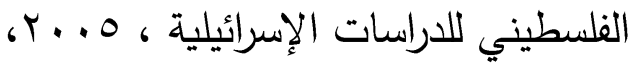

$$
\text { ص. }
$$

r. الوجيز فى تاريخ النيولييرالية، تأليف ديفيد

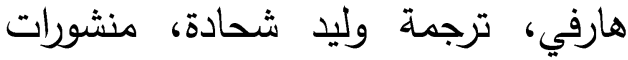

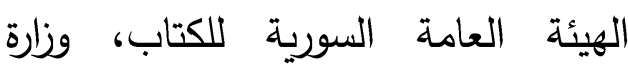

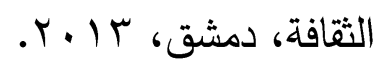

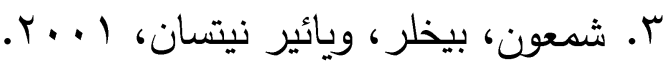

"رأس المال الإسرائيلي والعولمة"، لدى لئي

بنيامين كوهن، العودة الى ماركس، تل

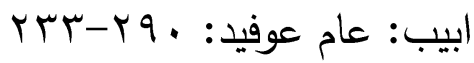

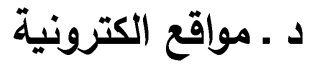

ا. أمير أون، "الشرطة تستعد لإخلاء خيام

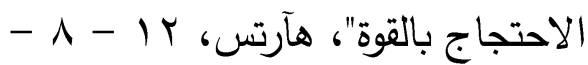

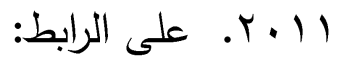

http://www.haaretz.co.il/hasite/obj ects/pages/PrintArticle.jhtml?item

$\mathrm{No}=1237896$

r. عادل شهيون ، »بيبى تورز شربية أخرى

لعائلة نيتانياهو، موقع جريدة الأهرام

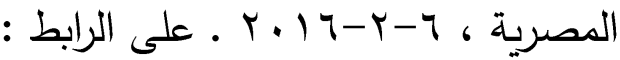

http://www.ahram.org.eg/News/13

$\underline{1808 / 115 / 475015}$

r. نبيل أرملي دور وسائل الإعلام الإسرائيلية

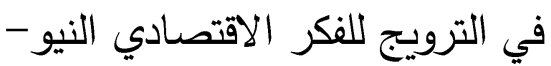

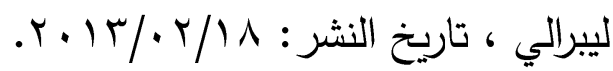

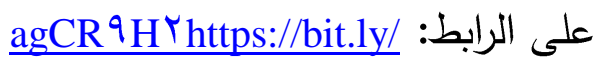

ع. الموقع الرسمي لمكتب رئيس الحكومة

http://www.pmo.gov.il/History/PastGover nments/Documents/ : part30.pdf r. أمطانس شحادة، صيف إسرائيلي ساخن،

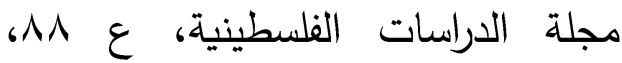
خريف 11 • بام.

r.د.جمال أحمد الرفاعي، إثكالية الاندماج

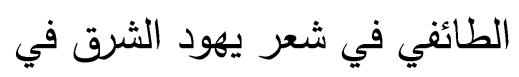

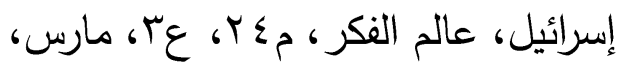

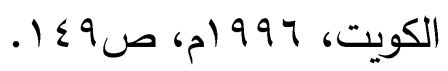

ع.د. حسام جريس، المشهـ الاقتصادي،

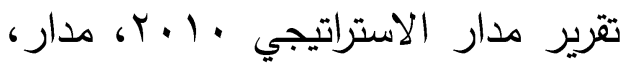
رام الله.

0. خيراردو لايينر، فصل الصيف الإسرائيلي

الذي كان والفصول التي قد تأتي، مجلة قضايا إسرائيلية، العدد 0؛، الاحتجاج الاجتماعي فى اسرائيل، دار المركز

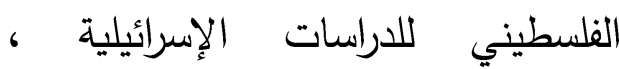
$.0 r+1 r$

7. مؤشرات الأوضاع الاقتصادية

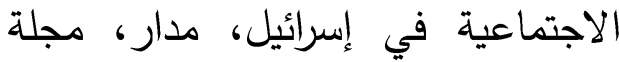

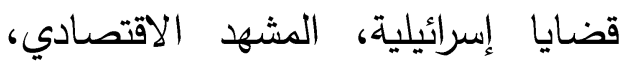

$$
\text { - } 9
$$

V. محمد جمال باروت : الحداثة الأولى من

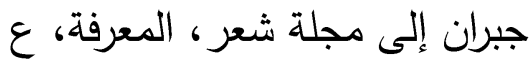



$$
\text { صV،VA }
$$

^. يوسف الخال :محاولات فى تفهيم الثعر صرالر

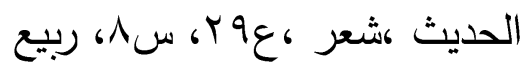

(1)

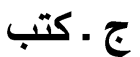


هآرتس، r -

http://www.haaretz.co.il/hasite/objects/ pages/PrintArticle.jhtml?itemNo=1237 ז. לקסיקון הספרות העברית החדשה יודית שחר (1959): https://library.osu.edu/projects/hebrew -lexicon/01720.php ז. לקסיקון אישים ומונחים، רוטשילד، הברון בנימין אדמונד דה (1845:(1934

https://main.knesset.gov.il/About/Le xicon/Pages/rotchild ad.aspx ع. לקסיקון ביו־ביבליוגראפי של

הספרות העברית החדשה :

https://library.osu.edu/projects/hebrewlexicon/02083.php
ثانيا : باللفة العبرية

$$
\text { أ ـ دوريات }
$$

ו. דני פילק־אורי רם • עלייתה ונפילתה

של המחאה החברתית(עד כה) ניתוח

סוציו -פוליטי • תיאוריה וביקורת 6 גיליון41، מכון וואן ליר ، ירושלים،

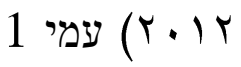

ץ. יוסף זעירא ، המחאה החברתית

וכלכלת ישראל ، מעשי משפט • כרך

$$
\text { הי זון } 213 \text { עיז }
$$

$$
\text { ب ـ المواقع الإلكترونية }
$$

ו. אמיר ארן • " המשטרה מתכוננת

לפנות את אוהלי המחאה בכוח "؛ 